\title{
Jakten på helsefremmende faktorer i epidemiologisk forskning: Eksempler fra Helseundersøkelsen i Nord-Trøndelag (HUNT)
}

\author{
Jostein Holmen ${ }^{1}$, Geir Arild Espnes ${ }^{2}$, Odd Håpnes ${ }^{3}$, Vegar Rangul ${ }^{1,4}$, Sven Svebak ${ }^{5}$, \\ Torgeir Sørensen ${ }^{6,7}$ og Töres Theorell ${ }^{8}$ \\ 1) HUNT forskningssenter, Institutt for samfunnsmedisin, Det medisinske fakultet, Norges teknisk- \\ naturvitenskapelige universitet (NTNU), Levanger \\ 2) Senter for helsefremmende forskning, NTNU, Trondheim \\ 3) Nasjonalt kompetansesenter for kultur, helse og omsorg, Levanger \\ 4) Avdeling for helsefag, Høgskolen i Nord-Trøndelag, Levanger \\ 5) Det medisinske fakultet, NTNU, Trondheim \\ 6) Det teologiske Menighetsfakultet, Oslo \\ 7) Religionspsykologisk senter, Sykehuset Innlandet HF, Hamar \\ 8) Karolinska Institutet, Stockholm
}

Korrespondanse: Jostein Holmen, HUNT forskningssenter, Forskningsvegen 2, 7600 Levanger

E-post: jostein.holmen@ntnu.no Telefon: 97567869 (m) 74075183 (k)

\begin{abstract}
SAMMENDRAG
Epidemiologisk forskning har tradisjonelt hatt fokus på å studere utbredelsen av sykdommer, risikofaktorer og årsaksfaktorer, og med forebygging som et hovedmål. Forskning på helsefremming har som hensikt å undersøke hvilke faktorer som er vesentlige for å styrke helsa til enkeltmennesker og befolkninger, og undersøke hvilke ressurser som kjennetegner mennesker og samfunn som utmerker seg med god helse. Kunnskapen fra forsking om helsefremmende faktorer skal brukes til å styrke folks helse og mestringsfølelse, enten de i utgangspunktet er friske eller syke. Det er derfor vesentlige forskjeller på både tenkning og empiri knyttet til helsefremming sammenlignet med forebygging. Helsefremming er i dag blitt en viktig innfallsvinkel til helseutfordringer verden over, og i helsefremmende arbeid er politiske beslutninger og policyarbeid en viktig del av prosessene. Men helsefremmende tenkning har enda ikke fått ordentlig fotfeste innen epidemiologien.

Målet med denne artikkelen er å beskrive mulighetene for å finne ny kunnskap om helsefremmende faktorer i norske befolkningsdatabaser, med Helseundersøkelsen i Nord-Trøndelag (HUNT) som et eksempel.

I HUNT er det allerede samlet ei rekke helsefremmende faktorer, som fysisk aktivitet, kosthold, sans for humor, sosial kapital, livssyn og deltakelse i kulturaktiviteter, og flere studier er publisert. Opplevelse av sammenheng (sense of coherence) og engasjement er andre viktige helsefremmende faktorer. Sammenhengen mellom musikk og helse har vært kjent lenge, og ei rekke studier har vist både nevrologiske, hormonelle, immunologiske, psykiske og sosiale effekter av musikk. Også for flere av de andre helsefremmende faktorene er det beskrevet biologiske effekter, og to oppfølgingsstudier av sans for humor har vist tydelig effekt på dødelighet.

Konklusjonen er at epidemiologiske studier kan være viktige kilder til kunnskap om helsefremmende faktorer, og slike studier kan dermed gi vesentlige bidrag til folkehelsearbeidet. Det aller beste vil være å satse på triangulering av kvalitative (intervju), deskriptive (kvantitativ kartlegging/tverrsnittsstudier) og eksperimentelle (kausale) metoder, alle med fokus på utvikling av kunnskap om en bestemt faktor basert på data fra en og samme populasjon.
\end{abstract}

This is an open access article distributed under the Creative Commons Attribution Licence, which permits unrestricted use, distribution, and reproduction in any medium, provided the original work is properly cited.

\section{INNLEDNING}

Epidemiologisk forskning har tradisjonelt hatt fokus på å studere utbredelsen av sykdommer, risikofaktorer og årsaksfaktorer bak utviklingen av sykdommer. Dette gjelder også den epidemiologiske forskningen i Norge (1). Helseforskning med fokuset på hva som fremmer helse mer enn på forebygging av sykdom, føres ofte tilbake til Engel (2), som satte spørsmålstegn ved den biomedisinske modellens tilstrekkelighet for å forklare helseutvikling, og Antonovsky (3) som først presenterte begrepet salutogenese (Figur 1). Disse to publikasjonene er blitt stående som hjørnesteiner knyttet til erkjennelsen av at det er bedre å styrke folks helse enn å vente til den er svekket av sykdom eller skade, og så behandle. Dette er i dag den fremherskende tenkningen $i$ helsepolitikk over hele verden (4), men har enda ikke fått fotfeste innen epidemiologien.

Det er vesentlige forskjeller på både tenkning og empiri knyttet til helsefremming sammenlignet med tenkning og empiri om forebygging av sykdom og ulykker (6). Verdens helseorganisasjons konferanse i Alma Ata i 1978 (7) og Ottawa-charteret fra 1986 (8) var sentrale milepæler. Men tenkning om helsefremming er langt eldre (9). For eksempel har krigerkulturer til alle tider hatt behov for å tenke på hva som fremmer best mulig helse hos sine krigere. Krigerne måtte ha god fysisk trening og den beste kosten for å 


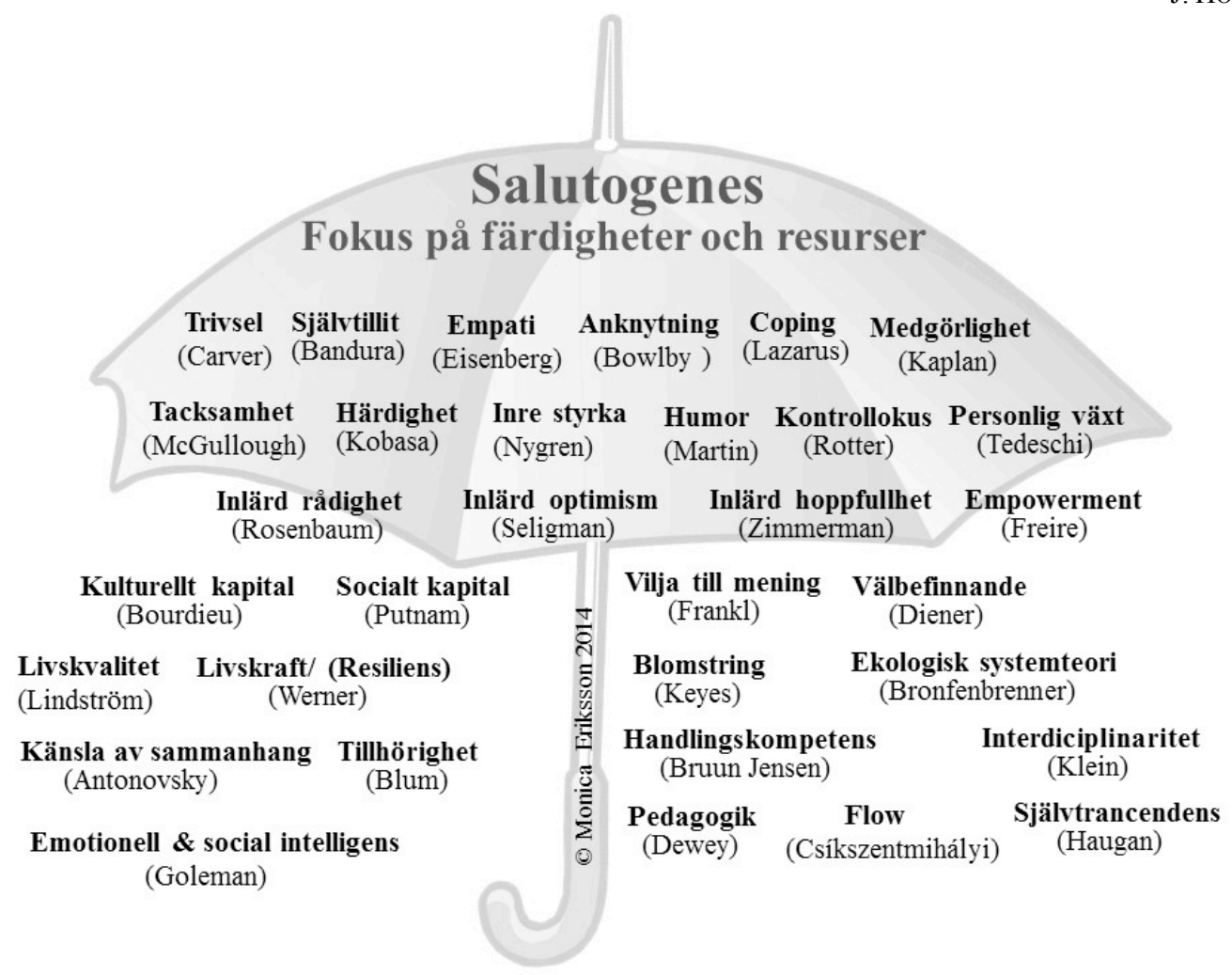

Figur 1. Faktorer som hører til under begrepet salutogenese (5).

bli sterke og holde seg friske, og for å bli herdet ble de også satt på psykiske prøver. I vår tid vektlegges også en helsemessig robust befolkning. Spørsmålet er hvordan vi skal oppnå dette.

Begrepet helse har vært i sterk utvikling. WHOs helsebegrep (10) er ofte diskutert og av mange karakterisert som utopisk, mens mange synes Peter F. Hjorts definisjon er lettere å forholde seg til: "Helse er overskudd i forhold hverdagens krav" (11). En slik definisjon betyr at helse kan være til stede både hos friske og syke. Et eksempel er kvinner over 80 år, med et snitt på tre kroniske sykdommer, der $70 \%$ oppgir å ha god helse (12). Denne helsedefinisjonen peker altså på at helse har sammenheng med ressurser og mestringsevne. Mennesker som opplever å ha tilstrekkelige ressurser til å takle livsutfordringene, opplever god helse (13).

Truslene mot folkehelsa er i stor grad de samme som i tidligere tider, særlig sykdom og ulykker. Men i tillegg er vi blitt oppmerksomme på mange andre trusler. Vi vet $\mathrm{i}$ dag for eksempel at helse varierer med sosial ulikhet. Vi vet at god utdanning er en god prediktor for god helse, og vi kjemper derfor mot frafall $\mathrm{i}$ skolene. Vi vet også at de sosiale og fysiske omgivelsene i stor grad har påvirkning på helsa. Derfor må vi sørge for en politikk som sikrer gode og trygge vilkår for oppvekst og gode bo-omgivelser. Vi har nå også god dokumentasjon på at vår livssynsorientering er viktig. Evne til å sette livet inn i en positiv sammenheng påvirker helsa positivt (3). Håpløshet, overvekt, nedstemthet, følelser av utilstrekkelighet og utenforskap settes i forbindelse med livsstilssykdommer. Disse sykdommene er i stor grad resultat av hvordan vi lever våre liv (9). Livsstilssykdommene er like hyppige $\mathrm{i}$ materielt fattige som rike samfunn (14). Den moderne tenkningen knyttet til helseutvikling dreier seg derfor ikke bare om tradisjonell forebygging. Men det er stadig mangel på sikker kunnskap om hva som er effektiv helsefremming (Figur 2).

Målet med denne artikkelen er å beskrive mulighetene for å finne ny kunnskap om helsefremmende faktorer i norske befolkningsdatabaser, med Helseundersøkelsen i Nord-Trøndelag (HUNT) som et eksempel. Artikkelen beskriver data som allerede er samlet og kunnskapen vi har om helsefremmende faktorer, og drøfter mulighetene for å utvikle framtidige befolkningsundersøkelser i retning mot mer helsefremmende tenkning.

\section{DAtAGrunnlaget PER I DAG}

Selv om helsefremming ikke har lange tradisjoner innen epidemiologisk forskning, har fokus endret seg de siste par tiårene, også i HUNT. HUNT består av tre omfattende befolkningsundersøkelser: I 1984-86 ble alle innbyggerne i fylket 20 år og eldre invitert første gang (HUNT1), og knapt 75.000 personer $(88,1 \%)$ deltok (15). Andre undersøkelse foregikk i 1995-97 da alle innbyggerne, 13 år og eldre, ble invitert (HUNT2). Denne gangen deltok omkring 70.000 personer, 20 år og eldre (70\%) (16), i tillegg til ca. 9000 ungdommer i alderen 13-19 år $(88,1 \%)$ (Ung-HUNT1) (17). Den foreløpige siste undersøkelsen foregikk i 2006-08 (HUNT3). Også denne gangen ble alle 13 år og eldre invitert, og til sammen ca. 51.000 personer $(54,1 \%)$, 20 år og eldre, deltok (18) i tillegg til 8200 ungdommer (78,4\%) (Ung-HUNT3) (17). 


\section{Områder for helsefremming i en mulig helseutvikling}

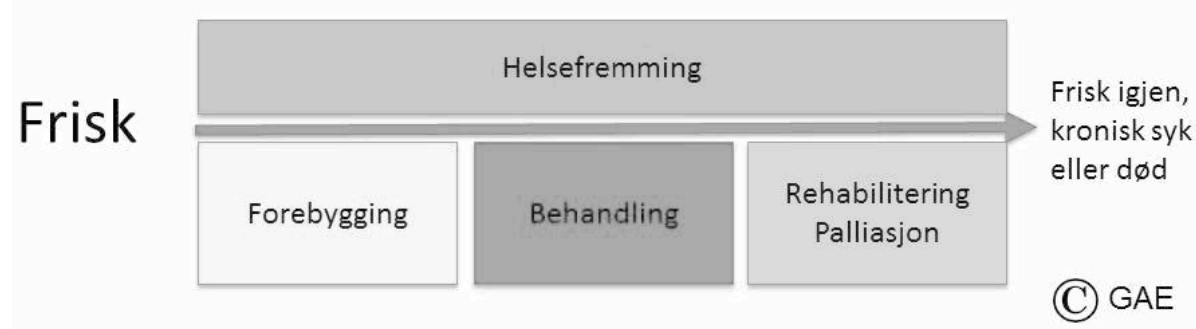

Figur 2. Forebygging og helsefremming er to ulike måter å tenke og arbeide på: Forebyggende helsearbeid prøver å hindre at folk blir syke. Helsefremmende arbeid tar sikte på å styrke folks helse og mestringsevne både hos friske og syke. Illustrasjon: Geir Arild Espnes.

Ved alle HUNT-undersøkelsene ble data samlet ved hjelp av spørreskjemaer og kliniske målinger. Deltakere som var 20 år og eldre fikk først et spørreskjema tilsendt $\mathrm{i}$ posten. Det ble fylt ut og tatt med til undersøkelsen. Der fikk de et nytt spørreskjema som de ble bedt om fylle ut heime og returnere i posten. Noen fikk også ekstra skjema, avhengig av om de oppga å ha spesielle sykdommer, som høyt blodtrykk, diabetes eller kreft. Disse skjemaene var stort sett sykdomsrettede. Ved HUNT2 og HUNT3 ble det også samlet inn blod- og urinprøver som er frosset og lagret i HUNT biobank.

HUNT1 (1984-86). Ved planleggingen av HUNT1 ble det helsefremmende perspektivet ikke drøftet, men selvrapportert fysisk aktivitet ble kartlagt med tre spørsmål, dvs. hyppighet, intensitet og varighet (19).

HUNT2 (1995-97). Under planleggingen av HUNT2 (16) ble det drøftet om det var mulig å finne flere helsefremmende faktorer, og for første gang ble spørsmål om sans for humor inkludert. Dessuten ble selvrapportert fysisk aktivitet kartlagt, men nå med bare to spørsmål (lett aktivitet, hard aktivitet). Sosial kapital ble kartlagt med tolv spørsmål om nærmiljøet og om venner. Det var flere spørsmål om kosthold, dvs. om antall måltider, antallet varme middager, spørsmål om bruken av brød, melk, ost, kosttilskudd og om bruken av fett i matlagingen (16).

HUNT3 (2006-08). Ved HUNT3 (18) det ble for første gang inkludert spørsmål om kulturdeltakelse, dvs. besøk på museum/kunstutstilling, konsert/teater/ kino, kirke/bedehus, idrettsarrangement, og spørsmål om hvor ofte en selv hadde drevet med foreningsvirksomhet, musikk/sang/teater, menighetsarbeid, friluftsliv, dans, trening/idrett. Det var også spørsmål om livssyn (kristent, humanetisk, ateistisk eller annet livssyn), om en tenker «det er ei mening med det» når det skjer vonde ting i livet, og om en søker hjelp hos Gud når en trenger styrke og trøst.

Fysisk aktivitet ble kartlagt ved å inkludere både spørsmålene som var brukt i HUNT1 (hyppighet, intensitet, varighet) og spørsmålene fra HUNT2 (lett og hard aktivitet). Kostholdet ble denne gangen grundigere kartlagt ved spørsmål om hvor ofte en spiste sju ulike typer matvarer, spørsmål om kosttilskudd og hvor mye en vanligvis drikker av seks ulike typer drikker. Det ble også spurt om måltider (seks måltider), om bruken av brød og om fett i matlagingen.

Det var to spørsmål om venner, dvs. om venner som kan gi hjelp ved behov og om venner en kan snakke fortrolig med. Tre spørsmål/utsagn om nærmiljøet ble inkludert, dvs. om fellesskapsfølelse, tillit og trivsel.

Ung-HUNT hadde aldersgruppa 13-19 år som målgruppe, dvs. elever ved ungdomsskolene og videregående skoler. Elevene fylte ut et 21 siders spørreskjema i en skoletime, og noen uker etterpå fikk skolene besøk av HUNT-personell som gjennomførte de kliniske undersøkelsene.

Ung-HUNT1 (1995-97). Spørreskjemaet omfattet flere spørsmål om idrett og fysisk aktivitet, bl.a. om hvilke aktiviteter, og hvor lenge eleven har vært engasjert i aktiviteten. Det var også spørsmål om fritidsaktiviteter, bl.a. lesing av bøker, bruk av musikk, samvær med venner, hobbyer og engasjement i lag og foreninger. Det var spørsmål om selvbilde (self esteem) og om spisevaner og kosthold, bl.a. bruken av 12 ulike matsorter (17).

Ung-HUNT2 (2000-01) omfattet elevene i videregående som også hadde deltatt i Ung-HUNT1 mens de ennå gikk i ungdomsskolen. Spørreskjemaet var omtrent identisk med skjemaet i Ung-HUNT1. Også spørreskjemaet ved Ung-HUNT3 (2006-08) omfattet de samme variablene som ved Ung-HUNT1 og UngHUNT2, men noen variabler ble endret. Det ble spurt om til sammen 20 ulike fritidsaktiviteter (17). Det ble også samlet genetisk materiale fra munnslimhinnen. En oversikt over alle variablene i HUNT finnes på HUNTs nettsider (20).

\section{FORSKNINGSFRONTEN}

Til tross for relativt kort forskningstradisjon innen epidemiologien, finnes det studier som viser sammen- 
heng mellom flere helsefremmende faktorer og konkrete helsemål. Men forskningsfeltene har kommet ulikt langt, og på noen områder er forskningen så vidt begynt.

Av de faktorene som har vært undersøkt i HUNT, er det gjort mest forskning på sammenhengen mellom sang, musikk og helse - både kvalitative og kvantitative studier. De metodiske tilnærmingene i de kvalitative studiene er varierte og resultatene usikre (21). Det er gjennomført to kunnskapsoversikter i Norge som belyser sammenhenger mellom kulturdeltakelse og helse og kulturelle virkemidler i behandling og folkehelsearbeid (22,23). På befolkningsnivå viste data fra HUNT3 at de som var kulturelt aktive, opplevde bedre helse, var mer tilfreds med livet sitt og erfarte mindre angst og depresjon (18). Undersøkelser indikerer at aktiv og systematisk kulturdeltakelse kan øke livslengden (24), redusere forekomsten av demens (25) og gi økt livskvalitet (26). Sang, musikk og andre kulturuttrykk har få bivirkninger og er egnet til å kombinere med medikamentell og kirurgisk behandling, og med andre miljøtiltak (27). Integrering av kulturelle tiltak i helsevesenet kan gi oppmuntring til pårørende og bedre ansattes tilfredshet $i$ arbeidssituasjonen $(28,29)$.

\section{SAMBANDET MELLOM MUSIKK OG HELSE HAR LANGE RØTTER}

Det er spennende å studere musikkens evolusjonære røtter på en vitenskapelig måte, men det er også vanskelig etter som kunnskap om urmenneskenes liv og atferd er begrenset fra da musikken faktisk oppsto. Dissanayake har spekulert $\mathrm{i}$ at musikalsk atferd og uttrykk kan ha medvirket til å forsterke båndene mellom foreldre og barn, og at denne funksjonen kan ha vært viktig for musikkens evolusjon (30). Hos naturfolk er musikk som regel en gruppeaktivitet, og andre teoretikere har foreslått at musikkens evne til å skape samhørighet kan ha vært avgjørende for musikkens evolusjon. Benzon har kommet med den drastiske formuleringen at musikken ble utviklet som «en metode for å kople sammen hjernene», altså en teknikk for å øke samholdet og samarbeidet mellom mennesker (31).

Det er vanskelig å bevise at regelmessig lytting til musikk eller aktiv spilling/synging i seg selv gir helsegevinst på sikt. Men en randomisert oppfølgingsstudie av eldre i USA som sang i kor en gang i uka i en toårs periode, fikk en bedre helseutvikling enn de i kontrollgruppen (32). Hos eldre finnes flere forklaringer på helseeffekter, slik som «noe å se fram til hver uke» og «sosialt samhold», noe som øker motivasjonen for å leve og ta vare på helsa. En får også trening av store muskelgrupper som diafragma og mage- og brystmuskulaturen (33), dessuten gir sangøvelser bedre koordinasjon mellom blodsirkulasjonen og åndedrettet. Under syngingen stimuleres også hormonet oxytocin, som har betydning for følelsen av samhold (34). Det ser dermed ut til at sang i kor rent biologisk kan stimulere til sosialt fellesskap (35). Det finnes flere studier som viser at immunsystemet blir stimulert under korsang $(36,37)$. I en randomisert studie ble det vist at de som begynner å synge i kor en gang i uka kan få økt testosteronproduksjon, i hvert fall det første halve året (38). En kan til og med få en gunstig endring av konsentrasjonen av fibrinogen (som er en del av immunsystemet og av betydning for blodkoaguleringen) og også på atheromatosen (åreforkalkningen) det forste året (39). Ingen har klart å vise at aktiv spilling eller sang er bedre for helsa enn passivt forbruk av musikk. Kanskje kan denne mangelen på forskjell skyldes at spilling eller synging for de profesjonelt aktive kan gi anspenthet og prestasjonsangst, og kanskje også føre til alkohol- og stoffmisbruk. De mest verdensberømte pop- og rockeartistene har økt dødelighet de første tjue årene etter at de har oppnådd berømmelse (40).

\section{MUSIKKENS VIRKNINGER}

Joseph Le Doux og medarbeidere oppdaget at følelsesladde stimuli i hjernen forplantes langs to ulike nervebaner som han kalte den «øvre» og den «nedre» banen $(41,42)$. En kunne også kalle dem for den langsommere og den raskere banen. Et musikkstimulus går først fra øret til en reléstasjon i thalamus, en struktur midt $i$ hjernen (Figur 3). En melodi er ofte forbundet med en viss emosjonell opplevelse. Dersom for eksempel en bestemt melodi assosieres med uro, blir følelsen av uro overført til en del av amygdala - en del av den emosjonelle hjernen. Den betraktes som en primitiv del, og våre emosjonelle reaksjoner kan sies å være omtrent de samme som hos pattedyr. Amygdala har en viktig funksjon når det gjelder stress og uro. Dersom uroen vekkes i amygdala av den urorelaterte melodien via den «nedre» og «raske» nervebanen, trigges raskt en stressreaksjon i hele kroppen. I tillegg til at uroimpulsen raskt når amygdala via den «nedre» nervebanen, blir melodien også overført til hjernebarken via den «øvre», mer langsomme banen. Hjernebarken tar seg av en fornuftsmessig, kognitiv tolking av melodien. Aktuelle spørsmål kan være: Hvilken melodi er det? Hvor har jeg hørt den før? Betyr melodien en fare for meg? Om den fornuftsmessige, kognitive tolkningen kommer fram til at impulsen faktisk innebærer en fare, blir informasjonen sendt til amygdala. Men da er amygdala for lengst i gang med sin stressreaksjon.

Et viktig begrep i den psykofysiologiske forståelsen av mulige helseeffekter av kulturelle aktiviteter er emosjonell kompetanse. I nevrobiologisk teori betyr det at de emosjonelle impulsene håndteres av andre deler av hjernen enn de fornuftsmessige, og at samarbeidet mellom disse hjerneavsnittene er avgjørende for helsa. For at samarbeidet mellom fornuftsdelen av hjernen og den emosjonelle hjernen skal fungere bra, må forbindelsen mellom høyre og venstre hjernehalvdel (corpus callosum: hjernebjelken) fungere optimalt. Studier med funksjonell magnetresonanskamera (fMRI) har vist at musikere har høy aktivitet i corpus callosum (43). I en studie basert på data fra det svenske tvillingregisteret 


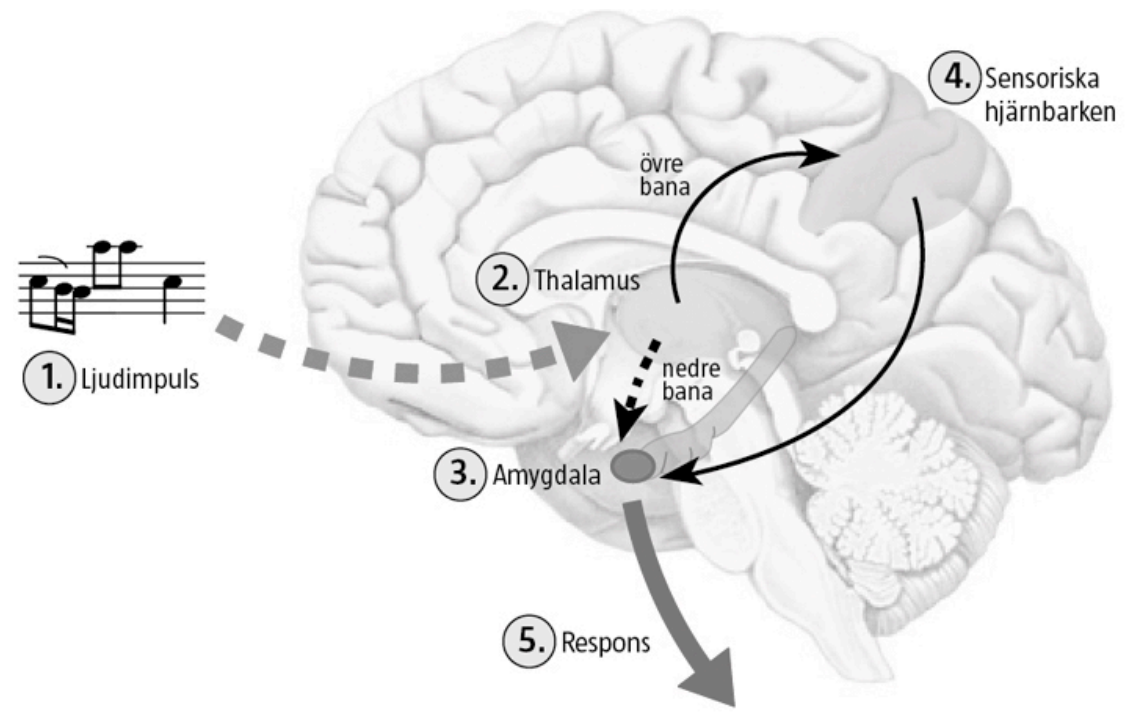

(C) Annika Röhl, Töres Theorell

Figur 3. Lyden av musikk går først fra øret til thalamus, deretter umiddelbart via den raske, nedre banen til amygdala, den «emosjonelle» hjernen. Musikkinntrykket går også via den øvre, mer langsomme banen til den sensoriske hjernebarken for en fornuftsmessig, kognitiv tolkning (42). Illustrasjon: Annika Röhl.

har en til og med funnet at voksne som øvde opp sine musikalske evner gjennom lang tid, slik at de fikk høy musikalsk profesjonalitet, hadde mindre alexitymi (problemer med å håndtere følelser) enn andre. Men den samme studien viste også at sambandet for det meste er genetisk bestemt (44-46). Intervensjonsstudier kan brukes til å studere om det er mulig å påvirke emosjonelle evner med musikktrening.

«Speilnevroner» i hjernen har avgjørende betydning når en person skal delta emosjonelt $i$ noe som skjer med en annen person. Det har vist seg at om noen ser en person som utfører en handling (f.eks. spiller et musikkstykke som iakttakeren også kan spille), så aktiveres de samme hjernecellene hos iakttakeren som hos den som spiller (47). Mekanismen i speilnevronene gjelder også for følelser, og dette er trolig noe av bakgrunnen for menneskelig empati. Slike prosesser med «intern stimulering» av hva andre gjør, tenker og føler, kan forklare noe av den makten som musikk ofte har over mennesker.

Det er påvist ei rekke psykofysiologiske effekter ved lytting til musikk. Effektene kan være sterke, og de er ulike avhengig av hva musikken inneholder (raskt/rolig tempo, diskant/bass, sterkt/svakt, oppadgående/nedadgående bevegelser, harmoniske/disharmoniske klanger, eller variasjon/stabilitet i melodien), tidligere erfaringer med samme type musikk og sammenhengen/stemningen når en lytter til musikken. Det er også påvist sterke effekter både på hjerte- og karsystemet (puls og pulsvariasjoner, blodtrykk), hormonsystemet (det sosiale hormonet oxytocin, kroppens eget morfin: beta-endorfin) og immunsystemet (fibrinogen) (42). Ulike former for musikkterapi er etablert for pasienter med Parkinsons sykdom, demens, depresjon, kroniske smerter og hjerneslag (27). En svensk randomisert studie av personer med nervøse tarm- plager (IBS) sammenlignet å synge i kor en gang i uka i ett år med å lytte på forelesninger og å ha gruppediskusjoner om IBS en gang i uka i samme periode. Fibrinogenkonsentrasjonen ble mer gunstig i korgruppen enn i den andre gruppen $(38,42)$.

\section{MAT, KOSTHOLD OG HELSE}

Sammenhengen mellom mat, kosthold og helse er mangesidig. Et sunt kosthold er en viktig forutsetning for god helse, mens det i dag er mye oppmerksomhet på et usunt kosthold som en årsak til overvektsepidemien vi ser i store deler av verden (48). Det er særlig høyt inntak av fett, sukker og salt, i tillegg til for høyt totalt energiinntak som har vært i fokus. Men i de siste årene er det observert økende tendens til et tvangspreget forhold til sunn mat, ortoreksi (49). Samtidig er det mye fokus på mat som ledd i spiseforstyrrelser som anoreksi og bulimi (50). Arbeid for et balansert og sunt kosthold er derfor en viktig del av det forebyggende helsearbeidet. En oversiktsartikkel som studerte effekten av tiltak for å fremme sunt kosthold hos barn og unge, inkluderte 42 enkeltstudier (51). De viste at skolebaserte informasjonstiltak for å fremme barn og unges kosthold (6-18 år) hadde positiv effekt over lengre tid. Flere av studiene fant en signifikant forskjell i kostholdet hos barn og unge i tiltaksgruppen sammenlignet med kontrollgruppen, i favør av de skolebaserte tiltakene. Tiltakene viste bedre effekt enn kontrolltiltakene på det generelle kostholdet, inntak av kullsyreholdige drikker og frukt og grønnsaker, men flere studier var preget av lav kvalitet og svakt design. Det er fortsatt store kunnskapshull i dette feltet.

Mat er ikke bare ernæring. Mat og kosthold kan også bety et spekter av opplevelser, som lukt, smak, synsinntrykk, sosialt fellesskap og kultur. Mat og kosthold kan 
derfor være viktige helsefremmende elementer, og dette er stadig et populært tema i ukeblader, TV og andre medier. Men det er gjort relativt lite forskning på sammenhengen mellom slike faktorer og helse (52).

\section{FYSISK AKTIVITET OG HELSE}

Allerede på 1950-tallet gjennomførte Morris og medarbeidere en studie blant ansatte i transportsektoren og blant postansatte i London. De viste at aktive menn (konduktører på bussen og postbud) hadde lavere dødelighet av hjerte- og karsykdom enn mindre aktive arbeidstakere (bussjåfører og sentralbordoperatører) (54). Disse tidlige studiene antydet hvilken rolle fysisk aktivitet har $\mathrm{i}$ å avverge tidlig død. Det er i dag godt dokumentert at moderat til høy fysisk aktivitet (voksne; 30 minutter moderat til høy intensitet daglig, barn og unge; 60 minutter fysisk aktivitet hver dag med moderat til høy intensitet) både har helsefremmende og forebyggende effekter.

La oss ta de helsefremmende først. Fysisk aktivitet øker forbrenningen og er dermed et hjelpemiddel ved slanking hos sterkt overvektige (55). Det er også velkjent at det å delta i fysisk aktivitet sammen med andre bedrer det sosiale nettverket, styrker psykisk helse og bedrer kondisjon og utholdenhet (6). Vi vet også at gode muligheter for å drive fysisk aktivitet og trening er en sterk pådriver til at det faktisk blir gjort. På den forebyggende siden vet vi at deltagelse i fysisk aktivitet reduserer risikoen for en rekke ikke-smittsomme sykdommer, som for eksempel koronar hjertesykdom, type 2 diabetes, høyt blodtrykk og kreft (56). Sammenhengen mellom fysisk aktivitet og hjerte- og karsykdommer er dokumentert $\mathrm{i}$ flere randomiserte kontrollerte studier der resultatene viser at fysisk aktivitet har gunstig effekt på blodlipider, blodtrykk og koronar hjertesykdom hos voksne (57). Disse observasjonene gir holdepunkter for at fysisk inaktivitet har årsaksmessig sammenheng med hjerte- og karsykdommer. Tverrsnittsdata viser at fysisk aktivitet er forbundet med reduserte symptomer på depresjon, angst og stressreaksjoner (58). Det er dessuten dokumentert at regelmessig fysisk aktivitet kan bedre psykisk velvære hos voksne, og fysisk aktivitet er anbefalt som et verktøy i terapi for angst og depresjon (59). Tverrsnittstudier har rapportert at redusert fysisk aktivitet er assosiert med økt forekomst av depressive symptomer (60). Type 2 diabetes og fedme har en tendens til å opptre i klynge sammen med andre kardiovaskulære risikofaktorer, som for eksempel økt blodtrykk og lavt HDL kolesterol (metabolsk syndrom), og er forbundet med lav fysisk aktivitet og kondisjon. Fysisk inaktivitet er en risikofaktor for type 2 diabetes fordi det fører til redusert insulinfølsomhet, og flere studier har vist at fysisk aktivitet er en viktig forebyggende faktor mot utvikling av type 2 diabetes (61) og ei rekke andre sykdommer (Tabell 1).

Det er økende evidens for at noe av den observerte effekten av fysisk aktivitet kan knyttes til sittetid, dvs. den tiden vi sitter stille i løpet av en dag (62). Det
Tabell 1. Helsemessige effekter av regelmessig fysisk aktivitet (56).

\begin{tabular}{ll}
\hline Hjerte- og karsykdom & Redusert risiko \\
Høyt blodtrykk & Redusert risiko \\
Overvekt og fedme & Redusert risiko \\
Diabetes & Redusert risiko \\
Kreft & Redusert risiko \\
Muskel- og skjelett & Forbedret \\
Psykisk helse & Forbedret \\
Funksjonell helse og forebygging av fall & Redusert risiko \\
\hline
\end{tabular}

kan bety at vi står foran et paradigmeskifte der stillesitting identifiseres som en folkehelseutfordring, selv om det er behov for mer kunnskap på dette området. Mennesket er skapt for bevegelse, mens samfunnsutviklingen har ført til at vi i vår moderne verden har relativt lavt fysisk aktivitetsnivå, og ikke minst at den teknologiske utviklingen har ført til at vi er blitt mer stillesittende (63).

Selv om vi har sikker kunnskap om at fysisk aktivitet er sunt, har vi ikke nok kunnskap om hvordan folk skal stimuleres til å drive fysisk aktivitet. Den viktigste pådriveren for fysisk aktivitet blant barn og unge er at det er gode muligheter for dette der de vokser opp (64). Helsefremmende boområder er et begrep som er blitt stadig mer brukt, og dette innbefatter både områdeplanlegging og arkitektur. Det er nødvendig å legge til rette for å kunne gå eller sykle til skole, arbeid og andre aktiviteter (aktiv transport). Omgivelsene må lages slik at de innbyr til aktiviteter (64). HUNT gir gode data på en rekke av folkehelseutfordringene knyttet til fysisk aktivitet, stillesitting og helse. Det er publisert flere artikler og rapporter som viser at aktivitetsmønsteret er i endring (65).

\section{SANS FOR HUMOR OG HELSE}

Det er en gammel oppfatning at sans for humor fremmer god helse, men det er fortsatt få studier som har undersøkt om dette faktisk er riktig. Et godt forsøk ble gjort $\mathrm{i}$ en serie med publikasjoner fra den prospektive databasen i California fra omkring 1920, kjent som "The Terman Life Cycle Study of Children with High Ability" (66-68). Navnet viser til Lewis Terman som ville studere livsløpet til begavede barn og derfor inkluderte tiåringer i en database. Sans for humor ble vurdert av foreldre og lærere (det sosiale bildet). Resultatene fra disse publikasjonene ble analysert omkring 80 år senere og viste en svak negativ sammenheng mellom sans for humor og livslengde. Barn som ble vurdert å ha stor sans for humor hadde en uventet tendens til å dø tidlig. Det motsatte resultatet av sans for humor ble publisert i 2006 da pasienter i SørTrøndelag, alle med kronisk nyresvikt, ble fulgt over to år (69). Denne studien viste betydelig redusert dødelighet hos de som skåret over medianen $\mathrm{i}$ en test på sans for humor. Sansen for humor ble der basert på en metode for selvrapportering (selvbilde).

Data fra 1069 elever i videregående skole i SørTrøndelag (by og land, jenter og gutter) viste at helse- 


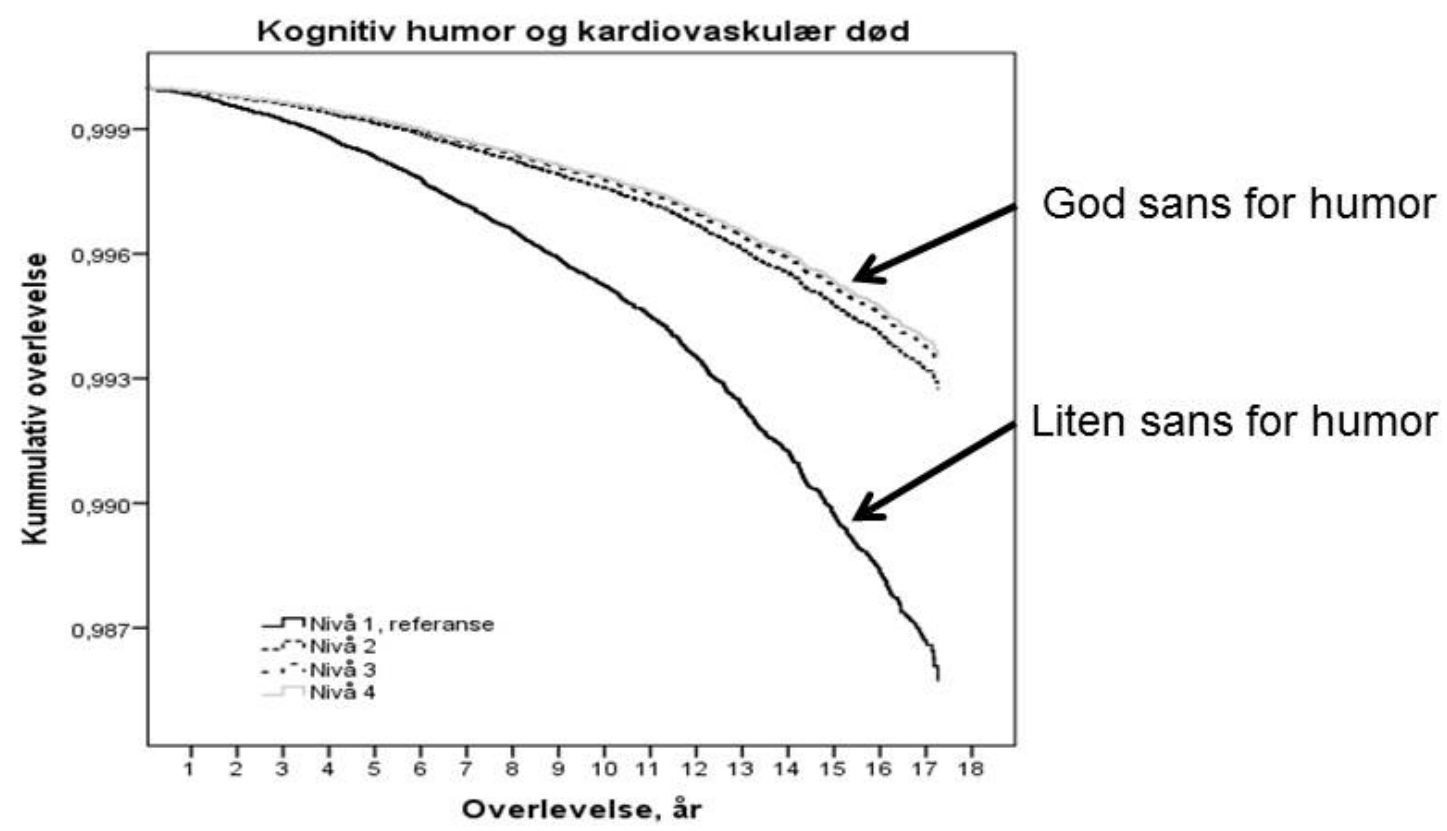

Figur 4. Sans for humor og dødelighet av hjerte- og karsykdommer. 15 års oppfølging etter HUNT2 (75)

plagene hos ungdommer i Trondheim var større enn hos ungdommer på landsbygda. Og sansen for vennlig humor var større hos ungdommer på landet enn i Trondheim. Jentene i byen hadde flest helseplager, både fysisk og psykisk (70). Resultatene viste også at ungdommer med opplevelse av både mening i daglig liv og sans for humor var minst plaget av subjektivt stress og kroppslige plager (71). Forekomsten av angst og depresjon var uventet høy hos disse ungdommene, og den var knyttet til personlighet, kjønn, bosted og sans for humor (72). Samlet viste resultatene at ungdommenes psykiske og fysiske helse både var forklart med kjønn, bosted (lokal kultur), personlighet (inkludert sans for humor) og opplevelse av mening i daglig liv.

Skårer på sans for humor fra omkring 55.000 voksne HUNT2-deltakere viste ingen klar sammenheng med sykelighet (73), men overlevelsen etter syv år var betydelig høyere hos de som skåret over medianen på den kognitive komponenten i sans for humor (74). Disse data ga ingen mulighet for å se effekter på ulike årsaker til død. En ny studie av overlevelse etter femten til sytten år har imidlertid vist at den kognitive komponenten i sans for humor reduserte risiko for å dø av hjertekarsykdom og infeksjoner hos kvinner og av infeksjoner hos menn (Figur 4). Derimot var det ingen sammenheng med kreft og andre årsaker til død (75).

Lattermildhet (munterhet) er en av flere komponenter i sansen for humor, og latter har først og fremst psykiske effekter slik som bedre humør en stund etter hjertelig latter. Men de fleste studiene har vist at kraftig latter kan føre med seg flere helseproblemer enn gode effekter, som at risikoen øker for inkontinens, brokk, synkope, hjerneslag og hjerteinfarkt $(74,76)$.

Det er foreløpig gjort lite forskning på hvilke mekanismer som utløses ved ulik sans for humor. Men sans for humor er et psykologisk kjennetegn og må derfor virke gjennom sentralnervøse mekanismer. Resultatene fra HUNT-forskningen om overlevelse har vist at det er den kognitive komponenten som først og fremst fremmer helse. Tankestrukturen i humor er beskrevet som varianter av kognitive strukturer der konsekvensen er "deminishment" (77) eller nedskalering, ofte i form av det motsatte av krisemaksimering. Dermed er det mulig at sans for humor virker helsefremmende gjennom å beskytte mot mobilisering av stressreaksjoner beskrevet som "fight or flight" for mer enn tre generasjoner siden.

Måling av IgA i spytt før og etter eksponering for mentalt stress hos personer med høye og lave skårer på sans for humor har vist at nivået av IgA var godt vedlikeholdt etter eksponering hos de med stor sans for humor, mens det var redusert hos de med lave skårer på sans for humor (74). Denne effekten av sans for humor kan tyde på at stor sans for humor beskytter mot antigener i slimhinner og derfor mot infeksjoner gjennom luftveiene. Resultatene fra HUNT om overlevelse etter femten år støtter denne antakelsen (75).

\section{LIVSSYN OG HELSE}

En rekke internasjonale studier, de fleste amerikanske, har vist signifikante sammenhenger mellom dimensjoner ved livssyn og utvalgte helsefaktorer $(78,79)$. Betydelige forskjeller innen kultur, livssynspraksis og helsevesen gjør imidlertid at det er vanskelig å overføre disse resultatene uten videre til norske forhold (80).

Tverrsnittstudier fra HUNT3 har vist at det er en invers sammenheng mellom religiøs aktivitet og blodtrykk (81). Det er også påvist en signifikant invers 
sammenheng mellom religiøs aktivitet og depressive symptomer. Denne sammenhengen var sterkere i gruppen som hadde opplevd dødsfall i nær familie det siste året (82). I en studie der deltakelse på kulturelle arrangementer ble sammenliknet med religiøs aktivitet, så man at kirkegang hadde en like sterk signifikant positiv relasjon til tilfredshet med livet som deltakelse ved sportsarrangement (83). En longitudinell studie basert på HUNT2 og HUNT3 viste at hodepine førte til økt religiøs deltakelse i kirke og bedehus (84). Studiene over viser også at sammenhengene ofte er sterkere blant menn enn kvinner. Dette bryter med amerikanske undersøkelser og illustrerer nødvendigheten av kontekstspesifikke studier.

Ulike komponenter i livssyn kan samvariere både positivt og negativt med mental og fysisk helse. Majoriteten av studier peker imidlertid på positive sammenhenger. I longitudinelle studier er det vist at for eksempel religiøs aktivitet og religiøs forpliktelse fører til lavere nivåer av angst og depresjon, lavere forekomst av livsstilsykdommer og større overlevelse. I litteraturen forklares slike sammenhenger hovedsakelig av tre faktorer (85). Det er påvist en direkte sammenheng mellom religiøsitet og mental helse (86). Samtidig er mental helse en av flere mulige forklaringsvariabler for relasjonen mellom religiøsitet og fysisk helse $\mathrm{i}$ en psykonevroimmunologisk sammenheng $(78,79)$. En annen forklaringsfaktor er sosialt nettverk. Det er kjent gjennom de siste femti år at nettverk er en viktig faktor for helse generelt (87). En rekke studier i livssyns- og helselitteraturen har pekt på at religiøse sosiale nettverk i mange tilfeller aksentuerer betydningen av sosialt nettverk. En tredje forklaringsfaktor er livsstil. I mange religiøse fellesskap og sammenhenger bruker man mindre tobakk og alkohol, i en del grupper gjøres bestemte valg med hensyn til kosthold, man har færre partnere og lever regelmessige liv og tar også andre valg med hensyn til livsstil. Slike levesett har betydning for forekomsten av kardiovaskulære sykdommer og kreft, og dermed for overlevelse (88).

\section{OPPLEVELSE AV SAMMENHENG}

Opplevelse av sammenheng (OAS: sense of coherence) er Aron Antonovskys idé om hvordan helse vedlikeholdes og utvikles i modellen om salutogenese (13). Opplevelse av sammenheng kommer fra Antonovskys intervju av personer som overlevde Holocaust. Han var interessert i hvordan mennesker takler ekstremt stress, men endte opp med en teori om opprinnelse til og utvikling av helse. Opplevelse av sammenheng består av tre viktige komponenter; begripelighet, håndterbarhet og meningsfullhet. Selv om det har vært antydet at OAS kan beskrives som et personlighetstrekk, hevdet Anotonovsky aldri at OAS var det. Han hevdet at OAS, i motsetning til et personlighetstrekk, utvikles og endres hele livet, og den er avgjørende for hvordan vi håndterer situasjoner $\mathrm{i}$ livet $\mathrm{og}$ dermed også for vår helseutvikling (3). Den grunnleggende idéen er at det er ulike faktorer som bestemmer helseutvikling og sykdomsutvikling, og at OAS er viktig for helseutviklingen.

I de senere årene har forskningen om hvilken betydning OAS har for helseutvikling skutt fart, og stadig nye måter å måle OAS er blitt lansert (13). Det er blitt vist hvordan OAS er viktig i ulike områder av livet. Arbeidshelseforsking er et slikt område, og derfor er mål på OAS inkludert i flere undersøkelser (89). OAS ser også ut til å være viktig for helsefremming blant mennesker med psykiske lidelser (90) og i forebygging av sykdom (14). Ny forskning viser hvordan en sterk OAS styrker både enkeltmennesker og samfunn (M. Mittelmark (red): Handbook of Salutogenesis. Springer, under utgivelse, 2016). Resultatene fra en finsk tvillingundersøkelse antydet at OAS kan knyttes til arvematerialet (91).

Det kan vise seg vanskelig å finne gode forklaringsmodeller for effekter av OAS. Opplevelser er sammensatte, og det er derfor neppe en enkeltfaktor som gir disse opplevelsene. Samspillet mellom psykologi, omgivelser og indre fysiologisk miljø er komplisert. Derfor vil noen hevde at OAS kommer inn under samlebegrepet økologiske helseteorier, mens andre vil si at OAS passer inn i en typisk stress-mestringsteori (92). Det er heller ikke noe i veien for å forklare OAS ut fra begge oppfatninger. Uansett er det gode indikasjoner på at OAS er kritisk for å utvikle og opprettholde god helse. Boken New Frontiers in Rescilient Aging (93) peker på at opplevelse av sammenheng er viktig for å beholde og utvikle god helse i eldre år, og at dette er særlig aktuelt $i$ vår tid med store demografiske endringer i mange områder på kloden.

\section{BETYDNINGEN AV ENGASJEMENT}

Engasjement er et begrep som særlig er benyttet i arbeidshelseforskningen, og er et positivt ladet ressursbegrep. Det argumenteres ofte med at engasjement er det motsatte av utbrenthet og kan sees på som endepunktene på et kontinuum (94). Utbrenthet har to dimensjoner som går fra utslitthet til vigør, og fra uengasjerthet til fullstendig dedikering til arbeidet. Disse to dimensjonene måles ofte med Oldenburg Burnout Inventory (95). Forskning fra de siste årene tyder på at vigør og dedikering er kjernedimensjonene i begrepet engasjement (96). Vigør karakteriseres med høye nivåer av energi og mental motstandskraft (resilience), mens dedikering karakteriseres med en følelse av betydning, entusiasme, inspirasjon og stolthet (95). Selv om forskningen på engasjement er lovende, er den fortsatt $i$ sin tidlige fase, og det er mange ubesvarte spørsmål om sammenhengen mellom engasjement og helse. Dette gjelder også ungdom, spesielt deres engasjement i skolegang, hvor det i 2011 kom en rapport som pekte på betydningen av slikt engasjement (97). Det er vanskelig å spekulere om biokjemiske eller fysiologiske mekanismer i denne sammenhengen, men det er kjent at positive opplevelser knyttet til stort en- 
gasjement hører sammen med produksjon av dopamin. Sannsynligvis er det her en positiv feedback-sløyfe: jo bedre en har det, jo mer dopamin frigjøres, som igjen fører til at en har det enda bedre og dermed forsterker den gode følelsen.

\section{DISKUSJON}

I denne oversikten har vi beskrevet noen helsefremmende faktorer og vist at disse faktorene kan påvirke helsetilstanden via både biologiske, mentale og sosiale mekanismer. Noen av faktorene er velkjente og etablerte i den epidemiologiske forskningen. Norske epidemiologiske studier har bidratt vesentlig om betydningen av fysisk aktivitet. Andre faktorer er mindre kjente, som kulturdeltakelse, musikk, livssyn, sans for humor, opplevelse av sammenheng (OAS) og engasjement. Her har epidemiologiske studier hittil bidratt i beskjeden grad, men det er noen unntak: HUNT3 viste at de som var kulturelt aktive, opplevde bedre helse, var mer tilfredse med livet sitt og erfarte mindre angst og depresjon enn de som ikke var kulturelt aktive (83). Denne studien vakte internasjonal oppmerksomhet, påvirket forskningen på feltet og har bidratt til at helsefremmende faktorer generelt, og kunst og kultur spesielt, har fått større plass i folkehelsearbeidet, i hvert fall i Norge. At den kognitive sans for humor skulle ha så tydelig effekt på dødeligheten etter HUNT2 (Figur 4) (75), stimulerer til oppfølgingsstudier for å forstå bedre hvordan vennlig sans for humor virker. Sans for humor kan øves opp gjennom god sosialisering og åpner derfor for nye metoder $i$ det helsefremmende arbeidet allerede gjennom gode rollemodeller i barnehagen. Senter for helsefremmende forskning, NTNU, er et eksempel der psykososialt arbeidsmiljø blant universitets- og høgskoleansatte ved 19 universiteter og høgskoler kartlegges. Der er bl.a. OAS inkludert (89).

Forskningen om helsefremmende faktorer er variert både i metodevalg, kvalitet og omfang. Studier av musikkinntrykk har gitt god innsikt i de basale virkningsmekanismene (psykologiske, fysiologiske, immunologiske, humorale) og i de sosiale effektene. Om det er tilsvarende effekter av de andre faktorene som er drøftet, vet vi foreløpig mindre om. Det er satt fram hypoteser om at stress kan være en felles faktor og at hormonelle, immunologiske og andre virkningsmekanismer kan forklare disse effektene (98).

Det er flere utfordringer når en skal vurdere studier om helsefremmende forskning. Ett eksempel er at noen kulturelle aktiviteter krever god helse i utgangspunktet, slik som å danse folkedans. En korsanger kan slutte å synge $\mathrm{i}$ et krevende kor når det blir problemer med stemmebåndene, pustefunksjonen, muskulaturen, eller når den fysiske utholdenheten svekkes. Er god helse hos korsangere og folkedansere da et resultat av hva som kreves for å være med på disse aktivitetene, eller er det tvert om slik at deltakelse i korsang og folkedans holder utøverne friske?
I befolkningsstudier er seleksjon alltid en utfordring. Det er ikke helt tilfeldig hvem som deltar. Også i HUNT3 ble det vist at de som møtte fram generelt var noe friskere enn de som ikke møtte fram (99). Dessuten er det ved slike store undersøkelser allid begrenset plass på spørreskjema, og dette har i mange tilfeller ført til at det ikke har vært plass til validerte sett av spørsmål. Resultatet har blitt at en ved hjelp av faktoranalyser og andre tilnærminger har valgt ut enkelte spørsmål fra et større sett av spørsmål. I HUNT2 ble det plass til bare ett spørsmål fra hver av tre dimensjoner i sans for humor (kognitiv, sosial, affektiv). I HUNT2 ble det også plass til bare to nivåer av egen-rapportert fysisk aktivitet (lett/hard), mens det både i HUNT1 og HUNT3 ble inkludert tre dimensjoner (hyppighet, intensitet og varighet). Slike suboptimale metoder reiser spørsmål om hva en faktisk måler. I noen tilfeller er det gjort valideringsstudier for å få innsikt i presisjonen av måleinstrumentet, slik som for fysisk aktivitet (100-103). Ved HUNT3 ble det målt flere livssynsdimensjoner, men bare én variabel for hver dimensjon ble inkludert («single item measures»). Derfor kunne ikke valideringen gjøres med kvantitativ tilnærming (faktoranalyse, intern konsistens). I stedet ble det gjennomført kvalitativt fokusgruppeintervju (104). Maksimalvariasjon tilrettela for felles oppfatninger blant deltakerne om hvordan variablene ble lest og forstått. Kvalitative funn ble sammenholdt med variablenes distribusjon i HUNT3 stratifisert på kjønn og alder. Med støtte fra begge metoder ble én variabel ekskludert fra videre analyser fordi den ble tolket ulikt innen forskjellige aldersgrupper. På en annen variabel ble svarkategorier slått sammen av samme årsak (80). Tilsvarende valideringsstudier burde vært gjort på flere målevariabler.

HUNT og andre populasjonsbaserte helseundersøkelser er hensiktsmessige for å identifisere helsefremmende faktorer $\mathrm{i}$ en befolkning. Samtidig har den kvantitative metodetilnærmingen $\mathrm{i}$ tverrsnittsstudier begrensninger. Vi kan påvise signifikante sammenhenger, men sammenhenger sier i seg selv ikke noe om kausalitet. Kvalitative dybdestudier kan ofte gi hjelp til å belyse hva som skjuler seg bak beta-skårer og odds ratioer (105). Derfor er det gode grunner for å utvide epidemiologiske studier med mixed-method design der kvalitative (intervju), kvantitative (tverrsnittsstudier/ survey) og eksperimentelle (kausale) metoder kan utfylle hverandre. Spesielt kan slik triangulering være effektiv i kunnskapsutvikling om de benyttes i studier av en og samme populasjon.

Selv om det her finnes et betydelig potensiale, ser ikke tenkningen omkring helsefremming ennå ut til å ha fått fotfeste innen epidemiologisk forskning. Forklaringen på dette kan være både manglende oppmerksomhet på disse faktorenes betydning og kort forskningstradisjon. Slike forhold kan i sin tur ha ført til vansker med å skaffe finansiering. Men det er behov for mer forskning på området. Den bør omfatte kulturdeltagelse, hva slags mekanismer som gir helseeffekter 
av kulturopplevelser, kulturens betydning for arbeidsmiljø, betydningen av arbeidsmiljø for god helse, hvilken betydning personlige egenskaper som engasjement og opplevelse av sammenheng har for våre måter å leve på, så vel som hvordan kulturtiltak kan implementeres i pleie og omsorg. Det er i HUNT mulig å gjøre mange studier på allerede innsamlede data, deriblant på lagrede blodprøver, der både hormonelle, immunologiske og genetiske analyser kan inngå. Men dette krever satsing fra forskningsmiljøene, et godt samarbeid mellom miljøene nasjonalt og bedre kontakter med internasjonale miljøer. Ideelt sett burde det vært etablert et forskningsfond i regi av NFR som starthjelp, inntil forskningsfeltet er så pass etablert at det er mulig å konkurrere på linje med annen, mer etablert forskning.

På sikt er det selvsagt også viktig at stadig flere helsefremmende faktorer blir inkludert $i$ framtidige befolkningsundersøkelser som HUNT4 med start i 2017, og i andre tilsvarende undersøkelser, som MoBa, Tromsø og andre CONOR-relaterte datainnsamlinger (106).

\section{KONKLUSJON}

Tradisjonell epidemiologisk forskning har hatt et sterkt fokus på utbredelsen av sykdommer, risikofaktorer og med forebygging som et hovedsiktemål. I denne artikkelen har vi pekt på at helsefremming er vesensforskjellig fra forebygging, og at flere kjente helsefremmende faktorer har stor betydning for folkehelsa. Likevel ser ikke tenkningen omkring helsefremming ennå ut til å ha fătt fotfeste innen epidemiologisk forskning. Med noen få unntak, bl.a. forskningen omkring fysisk aktivitet, er det gjort relativt lite forskning på helsefremmende faktorer basert på befolkningsstudier, til tross for at det er samlet flere relevante datasett, slik som i HUNT. Forklaringen på dette kan være både manglende oppmerksomhet på disse faktorenes betydning, en kort forskningstradisjon innen feltet og vanskelig finansiering. Befolkningsstudier representerer uansett et betydelig potensiale for å skaffe ny og bedre kunnskap, og slike studier kan dermed gi viktige bidrag til å bedre folkehelsa. Det beste utbyttet vil en få gjennom triangulering av kvalitative, kvantitative og eksperimentelle metoder.

\section{REFERANSER}

1. Næss Ø, Bakketeig LS (red). History of Epidemiology in Norway. http://www.ntnu.no/ojs/index.php/norepid. Norsk Epidemiologi 2015; 25 (1-2).

2. Engel GL. The need for a new medical model: a challenge for biomedicine. Science 1977; 196 (4286): 129-36.

3. Antonovsky A. Unraveling the Mystery of Health: How People Manage Stress and Stay Well. Jossey Bass Social and Behavioral Science Series, 1987.

4. Global Action Plan for the Prevention and Control of NCDs 2013-2020. World Health Organisation, 2013.

5. Lindström B, Eriksson M. Haikerens guide til salutogenese. Oslo: Gyldendal Norsk Forlag, 2015.

6. Espnes GA, Smedslund G. Helsepsykologi, 2. utgave. Oslo: Gyldendal Akademisk, 2009.

7. WHO, 1978. Declaration of Alma Ata. http://www.euro.who.int/_data/assets/pdf_file/0009/113877/E93944.pdf?ua=1.

8. WHO, 1986. Ottawa-charteret. http://www.who.int/healthpromotion/conferences/previous/ottawa/en/.

9. Espnes GA, Lindström B. Salutogenese - et viktig steg for å forstå helse. I: Haugan IG, Rannestad T, editors. Helsefremming i kommunehelsetjenesten. Oslo: Cappelen Damm Adademisk, 2014.

10. WHO definition of Health, $2015 \mathrm{http} / / / \mathrm{www}$.who.int/about/definition/en/print.html.

11. Fugelli P. Helse - slik folk ser det. Tidsskr Nor Lageforen 2001; 121: 3600-4.

12. Bergland A, Wyller TB. Construct and criterion validity of a Norwegian instrument for health related quality of life among elderly women living at home. Social Indicators Research 2006; 77: 479-97.

13. Lindstrøm B, Eriksson M. The Hitchhiker's Guide to Salutogenesis. Salutogenic pathways to health promotion. Helsinki: Folkhelsan, 2010.

14. Chittem M, Lindström B, Byrapaneni R, Espnes G. Sense of coherence and chronic illnesses: Scope for research in India. $J$ Soc Health Diabetes $2015 ; 3$ (2).

15. Holmen J, Midthjell K, Bjartveit K, Hjort P, Lund-Larsen P, Moum T, et al. The Nord-Trøndelag Health Survey 1984-86. Purpose, background and methods. Participation, non-participation and frequency distributions. Verdal: Senter for samfunnsmedisinsk forskning, Statens institutt for folkehelse, Report No. 4, 1990.

16. Holmen J, Midthjell K, Krüger Ø, Langhammer A, Holmen T, Bratberg G, et al. The Nord-Trøndelag Health Study 1995-97 (HUNT 2). Objectives, contents, methods and participation. Norsk Epidemiologi 2003; 13 (1): 19-32.

17. Holmen TL, Bratberg G, Krokstad S, Langhammer A, Hveem K, Midthjell K, et al. Cohort profile of the Young-HUNT Study, Norway: A population-based study of adolescents. Int J Epidemiol 2014; 43 (2): 536-44.

18. Krokstad S, Langhammer A, Hveem K, Holmen TL, Midthjell K, Stene T, et al. Cohort Profile: The HUNT Study, Norway. Int J Epidemiol 2013; 42 (4): 968-77. 
19. Holmen J, Midthjell K, Forsen L, Skjerve K, Gorseth M, Oseland A. Helseundersøkelsen i Nord-Trøndelag 1984-86: Fremmøtet og sammenlikning av de som møtte og ikke møtte. Tidsskr Nor Lageforen 1990; 110 (15): 1973-7.

20. Helseundersøkelsen i Nord-Trøndelag (HUNT). http://www.ntnu.no/hunt, 2015.

21. Balsnes A. Sang og velvære. En kartlegging av eksisterende forskning om sangens effekter. Norsk visearkiv 2010.

22. Knudtsen MS, Holmen J, Håpnes O. Kulturelle virkemidler i behandling og folkehelsearbeid. Tidsskr Nor Logeforen 2005; 125 (24): 3434-6.

23. Knudtsen MS, Holmen J, Håpnes O. Hva vet vi om kulturdeltakelse og helse? Tidsskr Nor Lageforen 2005; 125 (24): 3418-20.

24. Bygren LO, Konlaan BB, Johansson SE. Attendance at cultural events, reading books or periodicals, and making music or singing in a choir as determinants for survival: Swedish interview survey of living conditions. BMJ 1996; 313 (7072): 1577-80.

25. Verghese J, Lipton RB, Katz MJ, Hall CB, Derby CA, Kuslansky G, et al. Leisure activities and the risk of dementia in the elderly. N Engl J Med 2003; 348 (25): 2508-16.

26 Bowling A. Ageing well: quality of life in old age. Cambridge: Cambridge Univeristy Press, 2005.

27. Myskja A. Integrated music in nursing homes - An appoach to dementia care. Bergen: Universitetet i Bergen, 2012.

28. Götell E, Brown S, Ekman S-L. The influence of caregiver singing and background music on vocally expressed emotions and moods in dementia care: a qualitative analysis. Int J Nurs Stud 2009; 46 (4): $422-30$.

29. Clift S, Camic P. The Oxford Textbook of Creative Arts, Health, and Wellbeing. International Perspectives on practice, policy and research. Oxford: Oxford University Press, 2015.

30. Dissanayake E. If music is the food for love, what about survival and reproductive success? Musicae Scientiae 2008 (Spesial Issue: Narrative in Music and Interaction): 169-95.

31. Benzon WL, Hays DG. The evolution of cognition. 1990. Subst Use Misuse 2006; 41 (14): 1837-60.

32. Cohen G. New theories and research findings on the positive influence of music and art on health with ageing. Arts \& Health 2009; 1: 48-63.

33. Clift S, Hancox G, Morrison I, Hess B, Kreutz G, Stewart D. Findings from a Cross-National Survey on Choral Singing, Well-being and Health. Canterbury: Canterbury Christ Church University, 2008.

34. Grape C, Sandgren M, Hansson L-O, Ericson M, Theorell T. Does singing promote well-being? An empirical study of professional and amateur singers during a singing lesson. Integr Physiol Behav Sci 2003; 38: 65-74.

35. Kreutz G. Does singing facilitate social bonding? Music and Medicine 2014; 6: 51-60.

36. Beck R, Cesario C, Yousefi A, Enamoto H. Choral singing, performance perception and immune system changes in salivary immunoglobulin A and cortisol. Music Perception 2000; 18: 87-106.

37. Kreutz G, Bongard S, Rohrman S, Hodapp V, Grebe D. Effects of choir singing or listening on secretory immunoglobulin A, cortisol, and emotional state. J Behav Med 2004; 27: 623-35.

38. Grape C, Wikström B, Hasson D, Ekman R, Theorell T. Saliva testosterone increases in choir singer beginners. Psychother Psychosom 2010; 79: 196-8.

39. Grape C, Theorell T, Wikström B, Ekman R. Choir singing and fibrinogen, VEGF, cholecystokinin and motilin in IBS patients. Med Hypotheses 2009; 72: 223-5.

40. Bellis MA, Hennell T, Lushey C, Hughes K, Tocque K, Ashton JR. Elvis to Eminem: quantifying the price of fame through early mortality of European and North American rock and pop stars. J Epidemiol Community Health 2007; 61 (10): 896-901.

41. Le Doux J. The emotional brain. NewYork: Weidenfeld and Nicolson, 1998.

42. Theorell T. Psychological health effects of musical experienciences. Theories, studies and reflections in music health science. London: Springer, 2014.

43. Borsci G, Boccardi M, Rossi R, Rossi G, Perez J, Bonetti M, et al. Alexithymia in healthy women: a brain morphology study. J Affect Disord 2009; 114: 208-15.

44. Mosing MA, Madison G, Pedersen NL, Kuja-Halkola R, Ullen F. Practice does not make perfect: no causal effect of music practice on music ability. Psychol Sci 2014; 25 (9): 1795-803.

45. Schellenberg EG. Examining the association between music lessons and intelligence. Br J Psychol $2011 ; 102$ (3): 283-302.

46. Theorell TP, Lennartsson AK, Mosing MA, Ullen F. Musical activity and emotional competence - a twin study. Front Psychol 2014; 5: 774.

47. Bengtsson SL, Ullén F, Ehrsson HH, Hashimoto T, Kito T, Naito E, et al. Listening to rhythms activates motor and premotor cortices. Cortex 2015; 45: 62-71.

48. Midthjell K, Lee CM, Langhammer A, Krokstad S, Holmen TL, Hveem K, et al. Trends in overweight and obesity over 22 years in a large adult population: the HUNT Study, Norway. Clin Obes 2013; 3 (1-2): 12-20.

49. Haman L, Barker-Ruchti N, Patriksson G, Lindgren EC. Orthorexia nervosa: An integrative literature review of a lifestyle syndrome. Int J Qual Stud Health Well-Being 2015; 10: 26799. 
50. Bjørnelv S, Nordahl HM, Holmen TL. Psychological factors and weight problems in adolescents. The role of eating problems, emotional problems, and personality traits: the Young-HUNT study. Soc Psychiatry Psychiatr Epidemiol 2011; 46 (5): 353-62.

51. van CE, Maes L, Spittaels H, van Lenthe FJ, Brug J, Oppert JM, et al. Effectiveness of school-based interventions in Europe to promote healthy nutrition in children and adolescents: systematic review of published and 'grey' literature. Br J Nutr 2010; 103 (6): 781-97.

52. Kropf A. The culture of food. Am J Public Health 2009; 99 (4): 615.

54. Morris JN, Heady JA, Raffle PA, Roberts CG, Parks JW. Coronary heart-disease and physical activity of work. Lancet 1953; 265 (6796): 1111-20.

55. Vasconcellos F, Seabra A, Katzmarzyk PT, Kraemer-Aguiar LG, Bouskela E, Farinatti P. Physical activity in overweight and obese adolescents: systematic review of the effects on physical fitness components and cardiovascular risk factors. Sports Med 2014; 44 (8): 1139-52.

56. Global health risks: mortality and burden of disease attributable to selected major risks. WHO, 2009.

57. Kraus WE, Houmard JA, Duscha BD, Knetzger KJ, Wharton MB, McCartney JS, et al. Effects of the amount and intensity of exercise on plasma lipoproteins. $N$ Engl J Med 2002; 347 (19): 1483-92.

58. Dunn AL, Trivedi MH, O'Neal HA. Physical activity dose-response effects on outcomes of depression and anxiety. Med Sci Sports Exerc 2001; 33 (6 Suppl): S587-S597.

59. Paluska SA, Schwenk TL. Physical activity and mental health: current concepts. Sports Med 2000; 29 (3): $167-80$.

60. Motl RW, Birnbaum AS, Kubik MY, Dishman RK. Naturally occurring changes in physical activity are inversely related to depressive symptoms during early adolescence. Psychosom Med 2004; 66 (3): 336-42.

61. Borghouts LB, Keizer HA. Exercise and insulin sensitivity: a review. Int J Sports Med 2000; 21 (1): 1-12.

62. Chau JY, Grunseit A, Midthjell K, Holmen J, Holmen TL, Bauman AE, et al. Cross-sectional associations of total sitting and leisure screen time with cardiometabolic risk in adults. Results from the HUNT Study, Norway. J Sci Med Sport 2014; 17 (1): 78-84.

63. Katzmarzyk PT. Physical activity, sedentary behavior, and health: paradigm paralysis or paradigm shift? Diabetes 2010; 59 (11): 2717-25.

64. Heath GW, Brownson RC, Kruger J, Miles R, Powell K, Ramsey LT. The effectiveness of urban and land use and transport policies and practices to increase physical activity: A systematic review. J Phys Act Health 2006; 3 (Suppl 1): 55-76.

65. Krokstad S, Knutsen MS. Folkehelse i endring. Helselundersøkelsen i Nord-Trøndelag. HUNT 1 (1984-86) HUNT 2 (1995-97) - HUNT 3 (2006-08). Verdal: HUNT forskningssenter, NTNU. http://www.ntnu.no/documents/10304/1130562/folkehelse-i-endring-huntrapport-2011.pdf, 2011.

66. Friedman HS, Tucker JS, Tomlinson-Keasey C, Schwartz JE, Wingard DL, Criqui MH. Does childhood personality predict longevity? J Pers Soc Psychol 1993; 65 (1): 176-85.

67. Friedman HS, Tucker JS, Schwartz JE, Martin LR, Tomlinson-Keasey C, Wingard DL, et al. Childhood conscientiousness and longevity: health behaviors and cause of death. J Pers Soc Psychol 1995; 68 (4): 696-703.

68. Martin LR, Friedman HS, Tucker JS, Tomlinson-Keasey C, H Schwartz JE. A life course perspective on childhood cheerfulness and its relation to mortality risk. Pers Soc Psych Bull 2002; 28: 1155-65.

69. Svebak S, Kristoffersen B, Aasarød K. Sense of humor and survival among a county cohort of patients with end-stage renal failure: a two-year prospective study. Int J Psychiatry Med 2006; 36 (3): 269-81.

70. Jensen EN, Götestam KG, Svebak S. A descriptive study of personality, health and stress in high-school students (16-19 years old). Eur J Psychiatry 2004; 18: 153-62.

71. Svebak S, Götestam KG, Jensen EN. The significance of sense of humor, life regard, and stressors for bodily complaints among high school students. Int J Humor Res 2004; 17: 67-83.

72. Götestam KG, Svebak S, Jensen EN. The role of personality, mood, subjective health, and stress in depressive symptoms among high school students. Eur J Psyciatry 2008; 22: 121-9.

73. Svebak S, Martin RA, Holmen J. The prevalence of sense of humor in a large, unselected county population: Relation with age, sex and some health indicatiors. The Nord-Trøndelag Health Study (HUNT), Norway. Int $J$ Humor Res 2004; 17: 121-34.

74. Svebak S, Romundstad S, Holmen J. A 7-year prospective study of sense of humor and mortality in an adult county population: the HUNT-2 study. Int J Psychiatry Med 2010; 40 (2): 125-46.

75. Romundstad S, Svebak S, Holen A, Holmen J. A 15- year follow-up study of sense of humor and causes of mortality: The Nord-Trøndelag Health Study. Psychosom Med 2015 Nov 13 [Epub ahead of print].

76. Ferner RE, Aronson JK. Laughter and MIRTH (Methodical Investigation of Risibility, Therapeutic and Harmful): narrative synthesis. BMJ 2013; 347: f7274.

77. Apter MJ, Desselles M. Disclosure humor and distortion humor: A reversal theory analysis. Humor 2012; 25: 417-35.

78. Koenig HG, McCullogh ME, Larson DB. Handbook of Religion and Health. New York: Oxford University Press, 2001. 
79. Koenig HG, King DE, Carson VB. Handbook of Religion and Health, 2nd edn. New York: Oxford University Press, 2012.

80. Sørensen T. Epidemiological studies of religious behaviours and health in the Nord-Trøndelag Health Study (HUNT3), Norway. Thesis. Oslo: MF Norwegian School of Theology and Innlandet Hospital Trust, 2012.

81. Sørensen T, Danbolt LJ, Lien L, Koenig HG, Holmen J. The relationship between religious attendance and blood pressure: the HUNT Study, Norway. Int J Psychiatry Med 2011; 42 (1): 13-28.

82. Sørensen T, Danbolt LJ, Holmen J, Koenig HG, Lien L. Does death of a family member moderate the relationship between religious attendance and depressive symptoms? The HUNT Study, Norway. Depress Res Treat 2012; 2012: 396347.

83. Cuypers K, Krokstad S, Holmen TL, Skjei KM, Bygren LO, Holmen J. Patterns of receptive and creative cultural activities and their association with perceived health, anxiety, depression and satisfaction with life among adults: the HUNT study, Norway. J Epidemiol Community Health 2012; 66 (8): 698-703.

84. Tronvik E, Sørensen T, Linde M, Bendtsen L, Artto V, Laurell K, et al. The relationship between headache and religious attendance (the Nord-Trøndelag health study - HUNT). J Headache Pain 2014; 15 (1): 1.

85. Oman D, Thoresen C. Do Religion and Spirituality Influence Health. Handbook of the Psychology of Religion and Spirituality. New York: The Guilford Press, 2005.

86. Pargament K, Raiya H. A decade of research on the psychology of religion and coping: Things we assumed and lessons we learned. Psyke \& Logos 2007; 28: 742-66.

87. Cobb S. Presidential Address-1976. Social support as a moderator of life stress. Psychosom Med 1976; 38 (5): 300-14.

88. Fønnebø V. Mortality in Norwegian Seventh-Day Adventists 1962-1986. J Clin Epidemiol 1992; 45 (2): $157-67$.

89. Innstrand ST, Christensen M, Undebakke KG, Svarva K. The presentation and preliminary validation of KIWEST using a large sample of Norwegian university staff. Scand J Public Health 2015; 43 (8): 855-66.

90. Mjøsund NH, Eriksson M, Norheim I, Keyes CLM, Espnes GA, Vinje HF. Mental health as perceived by persons with mental disorders - an interpretative phenomenological analysis study. Int J Mental Health Prom 2015; 17 (4): 215-33.

91. Silventoinen K, Volanen SM, Vuoksimaa E, Rose RJ, Suominen S, Kaprio J. A supportive family environment in childhood enhances the level and heritability of sense of coherence in early adulthood. Soc Psychiatry Psychiatr Epidemiol 2014; 49 (12): 1951-60.

92. Folkman S, Lazarus R, Dunkel-Schetter C, DeLongis A, Gruen J. Dynamics of a stressful encounter. Cognitive appraisal, coping, and encounter outcomes. J Pers Soc Psychol 1986; 50 (5): 992-1003.

93. Fry P, Keyes C. New Frontiers in Resilient Aging. New York: Cambridge University Press, 2010.

94. Maslach C, Leiter M. Early predictors of job burnout and engagement. J Appl Psychol 2008; 93: 498-512.

95. Demerouti E, Bakker A. The Oldenburg Burnout Inventory: A good alternative to mesure burnout and work engagement. In: Halbesleben J, editor. Handbook of stress and burnout in health care. New York: Nova Science, 2008.

96. González-Romá V, Schaufeli W, Bakker A, Lloreta S. Burnout and work engagement: Independent factors or opposite poles? J Vocational Behav 2006; 68: 165-74.

97. Fredricks J, McColskey W, Meli J, Mordica J, Montrosse B, Mooney K. Measuring student engagement in upper elementary through high school: a description of 21 instruments (Issues \& Answers Report REL 2011No. 098). Washington, D.C.: U.S. Department of Education, Institute of Education Sciences, National Center for Education Evaluation and Regional Assistance, Regional Educational Laboratory Southeast, 2011. Retrieved from http://ies.ed.gov/ncee/edlabs.

98. Svebak S. Forlenger en god latter livet? Humor, stress og helse. Bergen: Fagbokforlaget, 2000.

99. Langhammer A, Krokstad S, Romundstad P, Heggland J, Holmen J. The HUNT study: participation is associated with survival and depends on socioeconomic status, diseases and symptoms. BMC Med Res Methodol 2012; 12: 143.

100. Kurtze N, Rangul V, Hustvedt BE, Flanders WD. Reliability and validity of self-reported physical activity in the Nord-Trøndelag Health Study (HUNT 2). Eur J Epidemiol 2007; 22 (6): 379-87.

101. Kurtze N, Rangul V, Hustvedt BE. Reliability and validity of the international physical activity questionnaire in the Nord-Trøndelag health study (HUNT) population of men. BMC Med Res Methodol 2008; 8: 63.

102. Kurtze N, Rangul V, Hustvedt BE, Flanders WD. Reliability and validity of self-reported physical activity in the Nord-Trøndelag Health Study: HUNT 1. Scand J Public Health 2008; 36 (1): 52-61.

103. Rangul V, Holmen TL, Kurtze N, Cuypers K, Midthjell K. Reliability and validity of two frequently used self-administered physical activity questionnaires in adolescents. BMC Med Res Methodol 2008; 8: 47.

104. Sørensen T, Lien L, Holmen J, Danbolt LJ. Distribution and understanding of items of religiousness in the Nord-Trøndelag Health Study, Norway. Mental Health, Religion and Culture 2012; 15 (6): 571-85.

105. Malterud K. Kvalitative metoder i medisinsk forskning. En innføring. Oslo: Universitetsforlaget, 2011.

106. Magnus P, Arnesen E, Holmen J, Stoltenberg C, Søgaard AJ, Tell GS. CONOR - COhort NORway: historie, formål og potensiale. Norsk Epidemiologi 2003; 13: 79-82. 